\title{
UJI EFEK ANALGETIKA EKSTRAK BUAH KAKTUS (Opuntia elatior Mill.) PADA MENCIT (Mus musculus) YANG DIINDUKSI ASAM ASETAT
}

\section{ANALGETICS EFFECT OF CACTUS FRUITS EXTRACT (Opuntia elatior Mill.) ON ACETIC ACID INDUCED MICE (Mus musculus)}

\author{
Gissa Amellia $^{1 *}$, Ihwan ${ }^{1}$, Akhmad Khumaidi $^{1}$ \\ ${ }^{1}$ Jurusan Farmasi, Fakultas MIPA, Universitas Tadulako, Palu, Indonesia
}

Received 25 Desember 2015, Accepted 30 Januari 2015

\begin{abstract}
ABSTRAK
Penelitian ini bertujuan untuk menguji efek analgetika ekstrak buah kaktus (Opuntia elatior Mill.) dan dosis yang paling efektif memberikan efek analgetika. Dalam penelitian ini digunakan metode geliat dengan menggunakan asam asetat $1 \%$ sebagai penginduksi. Kelompok I sebagai kontrol negatif menggunakan natrium karboksimetilselulose 1\%, kelompok II sebagai kontrol positif menggunakan suspensi aspirin dengan dosis 1,3 mg/20 g BB, kelompok III sebagai kelompok ekstrak buah kaktus diberikan pada dosis $50 \mathrm{mg} / \mathrm{kg} \mathrm{BB}$, kelompok IV dosis $100 \mathrm{mg} / \mathrm{kg} \mathrm{BB}$, dan kelompok V dosis $150 \mathrm{mg} / \mathrm{kg}$ BB. Hasil penelitian menunjukkan bahwa ekstrak buah kaktus memiliki efek analgetika ditinjau dari penurunan jumlah geliat mencit dengan persentase proteksi untuk dosis $50 \mathrm{mg} / \mathrm{kg}$ BB $(11,26 \%), 100 \mathrm{mg} / \mathrm{kg}$ BB $(42,10 \%), 150 \mathrm{mg} / \mathrm{kg} \mathrm{BB}(60,14 \%)$ dan kontrol positif $(75,34 \%)$, dimana pada kontrol positif menunjukkan persentase proteksi yang paling besar. Persentase efektivitas analgetika ekstrak buah kaktus pada dosis $50 \mathrm{mg} / \mathrm{kg}$ BB sebesar (14,4\%), $100 \mathrm{mg} / \mathrm{kg} \mathrm{BB}(55,36 \%)$, $150 \mathrm{mg} / \mathrm{kg}$ BB $(79,95 \%)$ dan kontrol positif (100\%). Data yang diperoleh di analisis menggunakan Kruskal Wallis. Hasil statistik menunjukkan perbedaan secara bermakna antara dosis $150 \mathrm{mg} / \mathrm{kg}$ BB dan kontrol positif. Ekstrak buah kaktus menunjukkan efek analgetika yang paling baik dalam mereduksi jumlah geliat mencit pada dosis $150 \mathrm{mg} / \mathrm{kg}$ BB dibandingkan dengan ekstrak buah kaktus dosis 50 dan $100 \mathrm{mg} / \mathrm{kg} \mathrm{BB}$.
\end{abstract}

Kata Kunci : Analgetika, Kaktus (Opuntia elatior Mill.), Geliat

\begin{abstract}
The aim of this study is determine the analgetic effect of cactus fruits (Opuntia elatior Mill.) extract and the most effective dose to giving analgetic effect. This study used writhing method by the injection acetic acid $1 \%$ as induced. Group I as a negative control used natrium carboxy methylcellulose $1 \%$, group II as a positive control used aspirin suspension which dosage was $1,3 \mathrm{mg} / 20 \mathrm{~g} \mathrm{BB}$, group III as a extract of cactus fruits give to dose $50 \mathrm{mg} / \mathrm{kg} \mathrm{BB}$, group IV dose $100 \mathrm{mg} / \mathrm{kg} \mathrm{BB}$, and group V dose $150 \mathrm{mg} / \mathrm{kg} \mathrm{BB}$. The result shows that cactus fruits extract to giving analgetic effect judging from the reduction strength writhing reflex to protection percentage at dose $50 \mathrm{mg} / \mathrm{kg} \mathrm{BB}(11,26 \%), 100 \mathrm{mg} / \mathrm{kg}$ BB $(42,10 \%), 150 \mathrm{mg} / \mathrm{kg} \mathrm{BB}(60,14 \%)$ and the positif control $(75,34 \%)$, at the positif control shows that higher protection percentage. Effectiveness percentage analgetic extract of cactus fruits at dose of $50 \mathrm{mg} / \mathrm{kg} \mathrm{BB}(14,4 \%), 100 \mathrm{mg} / \mathrm{kg}$ BB $(55,36 \%), 150 \mathrm{mg} / \mathrm{kg} \mathrm{BB}$ $(79,95 \%)$ and positif control (100\%). The data which is got from the calculation later is analyzed by Kruskal Wallis. The result showed that there is different significantly between dose $150 \mathrm{mg} / \mathrm{kg} \mathrm{BB}$ and the positive control. The extract showed a optimal analgetic effect characterized by a significant reduction in the number of writhes or abdominal stretches in mice with dose $150 \mathrm{mg} / \mathrm{kg}$ BB body weight used when compared to the cactus fruits extract dose 50 and $100 \mathrm{mg} / \mathrm{kg} \mathrm{BB}$.
\end{abstract}

Keywords : Analgetic, Cactus (Opuntia elatior Mill.), Writhing

*Corresponding author: Gissa Amellia, gissaamelliagresantria@ymail.com (ph: +62-821-8737-0735) 


\section{PENDAHULUAN}

Indonesia adalah negara kedua di dunia sesudah Brazilia yang memiliki sejumlah keanekaragaman hayati. Banyak tanaman di Indonesia yang dapat dimanfaatkan sebagai obat herbal (Agoes, 2007). Pengembangan tumbuhan obat baik di dalam maupun di luar negeri berkembang dengan pesat, terutama dalam bidang khasiat obat (Dalimarta, 2000). Menurut Badan Kesehatan Dunia (WHO), negara - negara di Afrika, Asia dan Amerika Latin menggunakan obat herbal sebagai pelengkap pengobatan primer yang mereka terima (World Health Organization, 2003).

Pengobatan dengan menggunakan tanaman herbal telah diwariskan secara turun temurun dan biasanya didasarkan pada pengalaman, tradisi, kepercayaan, yang ada di masyarakat serta tergantung dengan jenis tanaman di daerah setempat (Dalimartha, 2008; Muhlisah, 2007). Diperlukan upaya untuk menemukan obat alternatif yang murah, aman dan mudah di dapatkan terutama yang berasal dari tanaman yang memberikan efek analgetika. Salah satu tanaman yang dapat dimanfaatkan dalam pengobatan tradisional adalah buah kaktus.

Penelitian yang telah dilakukan oleh Sativa (2014) mengatakan bahwa gel ekstrak buah kaktus pada konsentrasi $10 \%$ memiliki efek antiinflamasi yang sebanding dengan Natrium diklofenak $1 \%$. Sedangkan hasil penelitian terdahulu, yang telah dilakukan oleh Chauhan, Sanjaykumar (2010) dalam bentuk sediaan jus buah kaktus dengan dosis $15 \mathrm{ml} / \mathrm{kg}$ memiliki efek analgetika pada mencit, akan tetapi pada penelitian terdahulu masih memerlukan penelitian - penelitian lanjutan untuk lebih mengutkan pembuktian adanya pengaruh analgetika dari jus buah kaktus.

Oleh karena itu pada penelitian ini, peneliti tertarik untuk meneliti lebih lanjut tentang pengaruh analgetika dan untuk mencari terapi alternatif yang berefek analgetika dengan menggunakan ekstrak etanol $70 \%$ buah kaktus terhadap penurunan jumlah geliat pada mencit yang diinduksi dengan asam asetat.

\section{METODE PENELITIAN}

\section{Bahan}

Simplisia buah kaktus, etanol 70\%, aquadest, aspirin ${ }^{\circledR}$ Bayer, natrium karboksi metil selulosa, asam asetat glasial, asam sulfat, serbuk magnesium, asam klorida, kloroform, $\mathrm{FeCl}_{3}$, pereaksi Dragendorff, aqua pro injeksi.

\section{Alat}

Alat-alat yang digunakan pada penelitian ini antara lain alat-alat gelas, timbangan hewan, neraca analitik $\left(O H A U S^{\circledR}\right)$, jarum suntik $1 \mathrm{ml}$, sonde oral, stopwatch $\left(\right.$ HANHART $\left.^{\circledR}\right)$, corong (IWAKI PIREX $^{\circledR}$ ), lumpang / stamfer, hot plate $\left(V_{E N D I L L E^{\circledR}}\right)$, batang pengaduk, spoit injeki, wadah maserasi, erlenmeyer (IWAKI PIREX ${ }^{\circledR}$ ), cawan porselin, gelas ukur (IWAKI PIREX ${ }^{\circledR}$ ), penguap vakum putar (rotary vacum evaporator), oven vakum $\left(E Y E L A^{\circledR} \mathrm{N}-\mathrm{I} 200 \mathrm{~B}\right)$ dan kandang mencit.

\section{Hewan Uji}

Hewan yang digunakan dalam penelitian ini adalah mencit jantan (Mus musculus) dengan berat badan $20-30 \mathrm{~g}$ berjumlah 25 ekor mencit sebagai hewan uji yang dibagi menjadi 5 kelompok dan masing - masing kelompok terdiri atas 5 ekor mencit. 


\section{Metode}

\section{Rancangan Penelitian}

Rancangan penelitian ini adalah penelitian eksperimental dengan menggunakan metode rancangan acak lengkap (RAL) yang dibagi ke dalam lima kelompok perlakuan, masing - masing terdiri dari kontrol negatif, kontrol positif, \& tiga dosis untuk kelompok perlakuan sebagai berikut :

Kelompok I : Na CMC 1\%

Kelompok II : Aspirin 1,3 mg/20g BB

Kelompok III : Dosis $50 \mathrm{mg} / \mathrm{kg} \mathrm{BB}$

Kelompok IV : Dosis $100 \mathrm{mg} / \mathrm{kg} \mathrm{BB}$

Kelompok V : Dosis $150 \mathrm{mg} / \mathrm{kg} \mathrm{BB}$

\section{Pembuatan Ekstrak}

Pembuatan ekstrak buah kaktus dilakukan secara maserasi dengan pelarut etanol 70\%. Simplisia buah kaktus yang telah dikeringkan ditimbang $250 \mathrm{~g}$ dimasukkan kedalam bejana maserasi. Selanjutnya direndam dengan menggunakan pelarut etanol $70 \%$ sebanyak 1 liter hingga pelarutnya berada $1 \mathrm{~cm}$ diatas permukaan sampel, direndam selama 3 x 24 jam dan diaduk setiap 1 x 24 jam. Filtrat yang diperoleh ditampung, kemudian diuapkan dengan alat rotary evaporator (suhu $70^{\circ} \mathrm{C}$ ) hingga diperoleh ekstrak kental etanol.

\section{Uji Penapisan Fitokimia}

Ekstrak buah kaktus yang telah didapatkan kemudian diuji kualitatif terhadap adanya senyawa alkaloid, flavonoid, fenolik, steroid, saponin, dan tanin di Laboratorium FarmakognosiFitokimia Program Studi Farmasi Fakultas MIPA Universitas Tadulako.

\section{Perhitungan dan Pembuatan Suspensi Aspirin}

Dosis aspirin ditentukan berdasarkan faktor konversi dosis manusia. Dosis lazim aspirin $=500 \mathrm{mg}$ satu kali pakai. Pemberian dosis didasarkan pada berat badan orang dewasa rata-rata $70 \mathrm{~kg}$. Konversi dosis manusia $70 \mathrm{~kg}$ ke mencit $20 \mathrm{~g}=0,0026$, maka dosis aspirin untuk manusia $70 \mathrm{~kg}=500 \mathrm{mg}$. Jadi konversi dosis manusia ke mencit $=$ dosis manusia $\mathrm{x}$ faktor konversi untuk mencit berat badan $20 \mathrm{~g}=500 \times 0,0026=1,3 \mathrm{mg} / 20 \mathrm{~g} \mathrm{BB}$. Sejumlah aspirin ditimbang dan disuspensikan dalam Na CMC $1 \%$.

\section{Penetapan Dosis Bahan Uji}

Dosis yang digunakan merujuk dari penelitian yang telah dilakukan oleh Cauhan, Sanjaykumar (2010) yaitu dengan menggunakan buah kaktus sebagai bahan uji, pada dosis 5\%, 10\% dan 15\%. Maka dalam penelitian ini ditetapkan dosis yang akan digunakan adalah $50 \mathrm{mg} / \mathrm{kg} \mathrm{BB}, 100$ $\mathrm{mg} / \mathrm{kg} \mathrm{BB}$, dan $150 \mathrm{mg} / \mathrm{kg} \mathrm{BB}$.

\section{Uji Efek Analgetika}

25 ekor mencit dibagi menjadi 5 kelompok, tiap kelompok terdiri dari 5 ekor mencit. Sebelum perlakuan mencit dipuasakan selam 18 jam dengan tetap diberi minum. Pada kelompok I yaitu kontrol negatif, mencit diberikan larutan $\mathrm{Na} \mathrm{CMC} 1 \%$, kelompok II yaitu kontrol positif mencit diberi aspirin sebagai pembanding, kelompok III, IV, dan V diberi ekstrak etanol buah kaktus dengan dosis 50, 100, dan $150 \mathrm{mg} / \mathrm{kg} \mathrm{BB}$, yang masing- masing diberikan secara oral, dibiarkan selama 30 menit dan diinduksi menggunakan asam asetat secara intraperitoneal. Kemudian respon geliat diamati dengan selang waktu 5 menit selama 60 menit. 


\begin{tabular}{ccc}
\hline No. & Perlakuan & Rata-rata \pm SD \\
\hline 1 & Kontrol & $176 \pm 26,1$ \\
& Negatif & \\
2 & Kontrol & $42,8 \pm 7,7$ \\
& Positif & \\
3 & Dosis 50 & $155 \pm 24,9$ \\
& $\mathrm{mg} / \mathrm{kg} \mathrm{BB}$ & \\
4 & Dosis 100 & $99 \pm 15,8$ \\
& $\mathrm{mg} / \mathrm{kg} \mathrm{BB}$ & \\
5 & Dosis 150 & $68,6 \pm 10,6$ \\
& $\mathrm{mg} / \mathrm{kg} \mathrm{BB}$ & \\
\hline
\end{tabular}

\section{Analisis Data}

Penelitian uji efek analgetika dilakukan dengan menghitung persentase proteksi bahan uji dengan rumus :

$\%$ Proteksi $=100-(\mathrm{p} / \mathrm{k} \times 100 \%)$

Untuk melihat persentase efektivitas analgetika bahan uji, dilakukan dengan membandingkan persen proteksi kelompok bahan uji terhadap persen proteksi kelompok kontrol positif (aspirin) yang dihitung dengan rumus :

$$
\begin{aligned}
& \% \text { Efektivitas }= \\
& \frac{\% \text { Proteksi kelompok bahan uji }}{\% \text { Proteksi kelompok kontrol positif }} \times 100 \%
\end{aligned}
$$

Data yang diperoleh dianalisa secara statistik dan dihitung persentase efektivitas analgetika dengan menggunakan metode Kruskal-Wallis danMann-Whitney.

\section{HASIL DAN PEMBAHASAN}

\section{Hasil}

Pengujian efek analgetika ekstrak buah kaktus dengan perbandingan dosis 50, 100, $150 \mathrm{mg} / \mathrm{kg} \mathrm{BB}$ dan $\mathrm{Na} \mathrm{CMC}$ sebagai kontrol negatif serta pembanding berupa aspirin sebagai kontrol positif dengan menggunakan mencit sebagai hewan uji menunjukkan hasil rata-rata jumlah geliat mencit dari tiap kelompok perlakuan yang dapat dilihat sebagai berikut:

Tabel 1. Hasil Rata-rata Jumlah Geliat Mencit Dari Tiap Kelompok Perlakuan

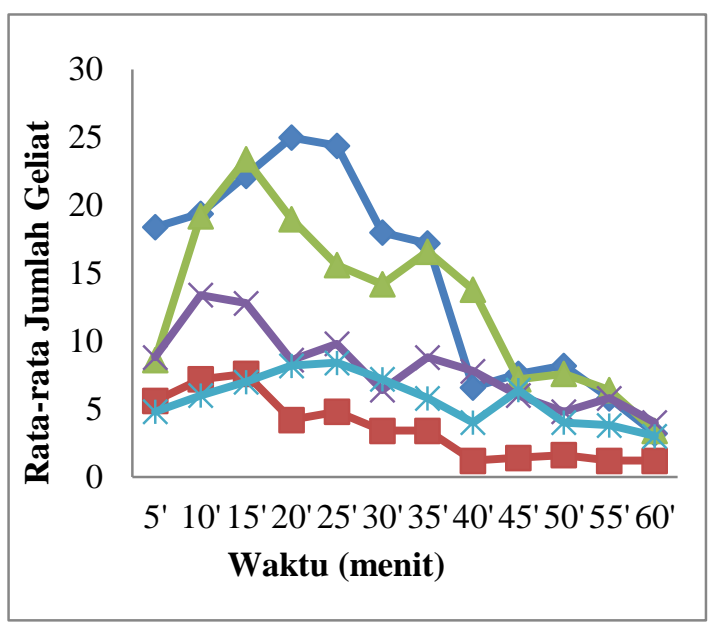

Gambar 1. Grafik Rata-rata Jumlah Geliat Mencit

\section{Pembahasan}

Analgetika adalah obat atau senyawa yang dalam dosis terapeutik dipergunakan untuk mengurangi rasa sakit atau nyeri tanpa menghilangkan kesadaran.

Pada penelitian ini digunakan ekstrak buah kaktus sebagai sampel yang akan diuji. Identifikasi tanaman dilakukan di Unit Pelaksana Teknis (UPT) Sumber Daya Hayati Sulawesi, Universitas Tadulako Palu dan diperoleh hasil bahwa tanaman yang telah diidentifikasi dan digunakan dalam penelitian ini adalah jenis tanaman kaktus (Opuntia elatior Mill.).

Berdasarkan pada penelitian ini digunakan ekstrak buah kaktus sebagai sampel yang akan diuji. Ekstrak kental buah kaktus diperolehsebanyak 74,3 g dan diperoleh rendemen yaitu sebanyak 
29,72\% (b/b).Hasil identifikasi terhadap kandungan kimia dari ekstrak buah kaktus diperoleh hasil positif senyawa dari golongan alkaloid, flavonoid, fenolik, steroid, saponin, dan tanin.

Dari pengamatan jumlah geliat mencit tiap 5 menit selama 60 menit, terlihat pada Gambar 1 menunjukkan bahwa mencit sudah mengalami geliat pada 5 menit pertama akibat pemberian asam asetat sebagai penginduksi nyeri. Pada menit ke 15 sebagian besar dari perlakuan menunjukkan geliat yang paling besar dan akan menurun kembali pada 5 menit berikutnya hingga menit ke 60 . Semakin sedikit jumlah respon geliat yang diberikan oleh kelompok mencit maka menunjukkan semakin baik khasiat dari bahan uji yang digunakan sebagai analgetika.

Berdasarkan hasil rata-rata jumlah geliat mencit dapat dihitung nilai persentase proteksi analgetika dan persentase efektivitas analgetika. Diperoleh nilai dari persentase proteksi dosis $50 \mathrm{mg} / \mathrm{kg}$ BB sebesar 11,26\%, dosis $100 \mathrm{mg} / \mathrm{kg}$ BB sebesar $42,10 \%$ dan dosis $150 \mathrm{mg} / \mathrm{kg}$ BB sebesar 60,14\% dan untuk kontrol positif memiliki persentase proteksi sebesar 75,34\%, dimana pada persentase proteksi kontrol positif (aspirin) memiliki persentase yang paling besar. Sedangkan persentase efektivitas analgetika ekstrak buah kaktus pada dosis $50 \mathrm{mg} / \mathrm{kg}$ BB sebesar 14,4\%, dosis 100 $\mathrm{mg} / \mathrm{kg}$ BB sebesar 55,36\%, dosis 150 $\mathrm{mg} / \mathrm{kg}$ BB sebesar 79,95\% dan untuk kontrol positif memiliki persentase efektivitas yang paling besar yaitu sebesar $100 \%$. Sehingga pada aspirin dosis 1,3 $\mathrm{mg} / 20 \mathrm{~g}$ BB dapat memberikan efektivitas analgetika yang paling efektifkemudian diikuti dengan dosis $150 \mathrm{mg} / \mathrm{kg} \mathrm{BB}$, dosis $100 \mathrm{mg} / \mathrm{kg} \mathrm{BB}$ dan dosis $50 \mathrm{mg} / \mathrm{kg} \mathrm{BB}$.
Pada ujistatistikdiperoleh nilai p; 0,000 dimana nilai $\mathrm{p}<0,05$. Maka dapat diambil kesimpulan bahwa terdapat perbedaan diantara masing-masing kelompok. Analisa hasil pengujian denganmembandingkanantar 2 kelompokperlakuanmenunjukkan bahwa kontrol positif mempunyai perbedaan yang bermakna dengan semua kelompok dosis ekstrak buah kaktus, artinya dari semua kelompok ekstrak buah kaktus tidak ada yang memiliki daya analgetika yang setara dengan kelompok kontrol positif aspirin 1,3 mg/20 g BB. Hal ini mungkin disebabkan ekstrak buah kaktus pada dosis 50, 100, dan $150 \mathrm{mg} / \mathrm{kg}$ BB belum memberikan pengaruh yang signifikan terhadap penekanan rasa sakit atau dosis ekstrak terlalu rendah atau ekstrak belum mencapai onset sehingga efek terapinya masih dibawah kelompok yang diberi aspirin $1,3 \mathrm{mg} / 20 \mathrm{~g}$ BB dalam menurunkan jumlah geliat mencit.

Ekstrak buah kaktus pada dosis 150 $\mathrm{mg} / \mathrm{kg}$ BB mempunyai efek analgetika yang paling baik dalam menurunkan rasa nyeri diantara ketiga kelompok dosis yang diberikan untuk efek analgetika. Serta perlu dilakukan pengujian mengenai uji toksisitas tanaman buah kaktus untuk mengetahui batas keamanan dan efek samping yang mungkin timbul pada penggunaan buah kaktus pada sediaan herbal.

\section{DAFTAR PUSTAKA}

Agoes, G. (2007). Teknologi Bahan Alam. Serial Farmasi Industri-2 Edisi revisi. Penerbit ITB. Bandung.

Chauhan, \& Sanjaykumar, P. (2010). Phytochemical\&pharmacological screening of fruit of Opuntia Elatior 
Mill (Thesis PhD). Saurashtra University. Hal, 36-41, 187-192.

Dalimartha, S. (2000). Atlas Tumbuhan Obat Indonesia.Jilid 1. Cetakan Pertama. Trubus Agriwidya. Jakarta.

Dalimartha, S. (2008). 1001 Resep Herbal. Penebar Swadaya. Jakarta.

Muhlisah, F. (2007). Tanaman Obat Keluarga. Penebar Swadaya. Jakarta.
Sativa, (2014). Uji Aktivitas Antiinflamasi Gel Ekstrak Buah Kaktus (Opuntia elatior Mill.) Pada Tikus (Rattus norvegicus L.) Yang Diinduksi Karagenan (Skripsi). Universitas Tadulako. Palu.

WHO, (2003). Traditional medi. diakses pada Desember 2014. From http://www.who.int/mediacentre/fa ctsheets/fs 134/en/. 